\title{
PHENOTYPIC AND MOLECULAR VARIABILITY OF MAIZE (ZEA MAYS L.) INDUCED WITH X-RAY
}

\author{
${ }^{*}$ Odunayo Joseph Olawuyi, 1,2 David Franklin Igata, ${ }^{3}$ Akinlolu Olalekan Akanmu, and \\ ${ }^{4}$ Abeeb Abiodun Azeez \\ ${ }^{1}$ Plant Genetics and Molecular Biology Unit, Department of Botany, University of Ibadan, \\ Ibadan, Oyo state, Nigeria \\ ${ }^{2}$ Department of Biological Sciences, Federal University Lokoja, Nigeria \\ ${ }^{3}$ Food Security and Safety Niche Area, Faculty of Natural and Agricultural Science, North-West \\ University, Private Bag X2046, Mmabatho, 2735, South Africa \\ ${ }^{4}$ Forestry Research Institute of Nigeria, Ibadan, Nigeria
}

Corresponding author: olawuyiodunayo@yahoo.com

\begin{abstract}
Ten genotypes of maize collected from National Center for Genetic Resources and Biotechnology (NACGRAB) were induced with X-ray for morphological and molecular assessment. The experimental design was complete randomized design with four replicates. Morphological and molecular statistical analyses of treated genotypes were conducted using SAS and Power Maker Packages, respectively while dendrogram was generated using Jaccards similarity coefficient using Unweighted Paired Group Method and Arithmetic Averages (UPGMA). The study revealed significant difference which is an indication of genetic variation of characters in treated maize. Genotype DTSR-Wco performed best in plant height $(62.35 \mathrm{~cm})$, leaf length $(62.35 \mathrm{~cm})$, number of leaves (3.15), leaf width $(7.55 \mathrm{~cm})$ and dry leaf biomass $(0.24 \mathrm{~g}) . X$-ray at $90 \mathrm{Kv} / \mathrm{mass}, 95 \mathrm{Kv} / \mathrm{mass}$ and $100 \mathrm{Kv} / \mathrm{mass}$ decreased plant heights to $54.25 \mathrm{~cm}, 53.87 \mathrm{~cm}$ and $54.10 \mathrm{~cm}$ respectively compared to Control. Heritability estimate was greater than $70 \%$ for all characters evaluated. Genotype TZM 1551 at $0 \mathrm{Kv} /$ mass yielded the highest concentration of DNA at $2841.60 \mathrm{ng} / \mathrm{ul}$ and the highest genomic DNA concentration was obtained at $95 \mathrm{Kv} / \mathrm{mass}$ for TZM 132 with 1.91\%. Primer BMC 1755 was most polymorphic with 58.77\% in treated maize genotypes. The plant height was strongly correlated with leaf length $(r=0.9)$, leaf width $(r=0.76)$ and number of leaves $(r=0.77)$. Principal component analysis showed close relationship between plant height (-0.03) and leaf length (0.05) compared with leaf width (-0.67) and number of leaves (0.69). Dry shoot biomass (0.05) was closely related to dry root biomass ($0.03)$ and dry leaf biomass (-0.04).
\end{abstract}

Key words: Mutation, Simple Sequence Repeat (SSR), Electromagnetic radiation, Electrophoresis

https://dx.doi.org/10.4314/jafs.v18i2.1

Journal of the Faculty of Agriculture and Veterinary Medicine, Imo State University Owerri website: www ajol.info; Attribution:Non- commercial CC BY-NC 


\section{INTRODUCTION}

Maize is a versatile monoecious plant useful as food for humans and animals as well as raw material for many industrial uses (Olawuyiet al., 2010; Dwivedi et al., 2016). Various techniques of inducing mutation increase variation artificially. Mutation occurs spontaneously as a result of alteration in genetic material and it changes the functions of the affected organism and its offspring (Grifith, 2005). Most mutation are harmful within the population but in some cases, mutation is beneficial in increasing agricultural values of some plants and animals.

Mutation breeding is a tool used by plant breeders for improvement of crops with narrow genetic base and plant development phenomena (Eze and Dambo, 2015). It has been widely adopted for genetic improvement of crops with desired agronomic and yield traits to enhance productivity. Electromagnetic radiation is a physical agent for inducing artificial mutation in plants which include; gamma rays, X-ray and ultra-violet ray (Eze and Dambo, 2015; Olawuyiet al., 2015).

$\mathrm{X}$-ray is a form of electromagnetic radiation exposed to organisms through solar system. It occupies 0.01-10 $\mathrm{nm}$ wave length $(\lambda)$ of the electromagnetic spectrum (Sabastine, 2012). Radiation is also known to aid plant growth to a certain extent but beyond the optimum dose level, it may be lethal to plant. X-ray is also known to induce chromosomal aberration in organisms (Xing et al., 2011). It has been observed that maize and other plants are negatively affected by mutagenic effects of high dose X-ray naturally sourced from the solar system. Again, the beneficial and lethal effect of X-ray have been Identified in humans medically but there is limited information on the phenotypic and genomic effects of X-ray on Maize plant. Therefore, the aim of this study was to assess the phenotypic and molecular variability of X-ray induced maize genotypes.

Simple sequence repeats (SSR) are mostly codominant and excellent markers used for carrying out studies in population genetics and mapping (Olawuyi and Onuoha, 2017). SSR makers have been used in many molecular studies due to their reproducibility, multi-allelic nature, codominant inheritance, relative abundance and good genome coverage (Anjali et al., 2018).

Simple sequence Repeat (SSR) works on the principle of microsatellite assay. It is based on the fact that it is highly polymorphic even between closely related lines. It requires low amount of DNA and can be automated easily for high throughput screening which can be exchanged between laboratories but are highly transferable between populations (Olawuyiet al., 2019).

\section{MATERIALS AND METHODS}

\section{Seed Collection and Experimental site}

The seeds of ten maizegenotypes were collected from National Center for Genetic Resource and Biotechnology (NACGRAB), Moor plantation Ibadan, Nigeria. The genotypes; TZM 1551, TZM COMP1 C 2 , TZM 132, TZE- WDTSR C4, OBA SUPPER F2, TZM 217, TZM 1300, DTSR- WC and TZM 140 were evaluated in the screen house of the Department of Botany, University of

Journal of the Faculty of Agriculture and Veterinary Medicine, Imo State University Owerri website: www ajol.info; Attribution:Non- commercial CC BY-NC 
Ibadan, Nigeria, while the molecular studies were carried out in the laboratory of bioscience unit of international institute of Tropical Agriculture (IITA), Ibadan, Nigeria.

\section{Soil Sterilization, Research Design and Exposure to $\mathrm{X}$-ray}

The Loamy soil sample was collected, sterilized to $60^{\circ} \mathrm{C}$, allowed to cool and then packed into perforated polythene bags. Each bag contained $7 \mathrm{~kg}$ of soil. The soil was watered and allowed to drain out before planting.

The experiment was laid out in a complete randomized design with four replicates. The various genotypes of maize were grouped into five and exposed to x-ray machine Silhouette VR of model E720Fx at the University College Hospital (UCH) Ibadan:

$85 \mathrm{kv} / \mathrm{Mas}, 90 \mathrm{kv} / \mathrm{mas}, 95 \mathrm{kv} / \mathrm{mas}$ and $100 \mathrm{kv} / \mathrm{mas}$, while unexposed (0kv/mas) was the control.

\section{Planting}

The seeds were planted in polythene bags filled with sterile soil, and spaced at a distance of $10 \mathrm{~cm}$ between treatment and $30 \mathrm{~cm}$ between the blocks.

All agronomic practices such as watering thinning etc. were duly carried out.

\section{Determination of Morphological Traits}

Data on growth characters (plant height, leaf length, and leaf width) were measured using meter rule while agronomic and yield related characters included; number of leaves, root lodging, number of tassels, length of tassels, dry root biomass, dry shoot biomass and dry leaf biomass.

\section{Molecular Studies}

\section{Harvesting and Viability Test}

Two weeks old fresh leaves of maize collected very early in the morning by 8:30am and were kept in cold environment at a temperature of $0^{\circ} \mathrm{C}$ to prevent denaturation of their DNA contents. Four leaf samples randomly collected per treatment from the four replicates were lyophilized at $80^{\circ} \mathrm{C}$ of liquid nitrogen. Viability test was carried out on the seeds plated in Petri dishes in order to select the viable ones.

\section{DNA Extraction}

The DNA was extracted from fresh and lyophilized young leaf sample of Maize according to Dellaporta et al., (1983) protocol modified in sodium dodecyl sulphate (SDS) extraction buffer. One gram of fresh young leaves was ground using mortar and pestle followed by the addition of one litter of extraction buffer. The extraction buffer was made up of isopropanol, $10 \mathrm{mg} / \mathrm{mi}$ RNASE A, $\beta$-mecaptoethanol, $1 \% \mathrm{PVP}(1 \mathrm{~g}$ of $100 \mathrm{ml}), 5 \mathrm{M} \mathrm{NaCl}(292.2 \mathrm{~g}$ in 1000) $1 \mathrm{M}$ Tris-HCl (121.4 in 1000ml, PH 7.5), 1 M EDTA (146.12g in $1000 \mathrm{PH}$ 8), 20\% SDS (200g SDS + 800ml of double distilled water), $70 \%$ ethanol $(70 \mathrm{ml}$ of ethanol in $100 \mathrm{ml}$ of double distilled water), $25 \mathrm{ml}$ CIA $(24 \mathrm{ml}$ chloroform $+1 \mathrm{ml}$ Isoamyl Alcohol), \%M potassium Acetate $(490.7$ in $1000 \mathrm{ml})$ stirred at $4^{\circ} \mathrm{C}$, low salt TE buffer $(10 \mathrm{ml} 1 \mathrm{M}$ Tris HCL, 2ml EDTA, 950ml of double distilled Journal of the Faculty of Agriculture and Veterinary Medicine, Imo State University Owerri website: www ajol.info; Attribution:Non- commercial CC BY-NC 
water and adjusted PH to 8). One litre of this buffer was prepared using $100 \mathrm{ml}$ Tris HCL $+50 \mathrm{ml}$ $0.5 \mathrm{M}$ EDTA $+100 \mathrm{ml} 5 \mathrm{M} \mathrm{NaCl}+1 \%$ PVP.

DNA extraction protocol involved grinding and digesting cellular constituent in order to release the content. Detergent such as sodium dodecyl sulphate (SDS), cetyl-trimethyl ammonium bromide (CTAB) was used for removal of membrane lipids. When the DNA was released, it was protracted from endogenous nucleases by inclusion of EDTA in the extraction buffer which is necessary for chelating magnesium ion that are significant co-factor for nucleases. The Eppendorf tube were thoroughly mixed and incubated at $65^{\circ} \mathrm{C}$ and precipitated using chloroform and Isoamyl alcohol. Also, RNAs are normally removed using RNA degrading enzyme known as RNase A. he DNA solution was transferred to $2 \mathrm{ml}$ Eppendorf tube and treated with RNases $(10 \mathrm{mg} / \mathrm{ml})$ for $1 \mathrm{hr}$. at $37^{\circ} \mathrm{C}$ and $1 \mathrm{ml}$ of chloroform: isoamyl alcohol (24:1) was added and centrifuged at 10,000 rpm for 10 minutes though polysaccharide-like contaminants are more tasking to remove. Since DNA will be released along with other compound like lipids, protein, carbohydrate or phenols, it needs to be separated from another compound by centrifugation. The DNA in the aqueous phase was then transferred into new Eppendorf tubes without disturbing the interphase and ice-cold ethanol was added to precipitate the DNA in salt solution (e.g. Sodium acetate) or alcohol (100\% isopropanol or ethanol), redissolved in sterile water or buffer. The pellets were washed in $70 \%$ ethanol air dried and finally dissolved 100ul of sterile double distilled water.

\section{Agarose Gel Electrophoresis and DNA Quantification}

The determination of DNA concentration extracted need to be measured using 1\% Agarose gel electrophoresis and detected UV illuminator or spectrophotometer. Agarose gel checks whether the DNA is degraded or not but estimating DNA concentration by visually comparing bands intensities of extracted DNA with molecular ladder of known concentration is too subjective. Spectrophotometer measures the intensity of the absorbance of DNA solution at $260 \mathrm{~nm}$ wavelength and also indicate the presence of protein contaminant but does not determine whether the DNA was degraded or not. This was doneto ascertain the quality and quantity of DNA extracted from the plant samples. Purity of DNA in the sample, dissolved in TE buffer was analyzed by checking the absorbance ratios at 260/280nm on Nano drop spectrophotometer followed by determination of concentration.

\section{Primer and Primer Sequences}

\section{Polymerase chain reaction (PCR) and Amplification of DNA product}

PCR reaction for SSRs was carried out in the presence of forward and reverse primers that anneal at the 5' and 3' ends of the DNA template. PCR fragment are usually separated on polyacrylamide gels in combination with $\mathrm{AgNO}_{3}$ staining, autoradiography or fluorescent detection system. Agarose gels (usually 3\%) with EtBr can also be used when differences in allele size among samples is larger than $10 \mathrm{bp}$.

Journal of the Faculty of Agriculture and Veterinary Medicine, Imo State University Owerri website: www ajol.info; Attribution:Non- commercial CC BY-NC 
Amplification of microsatellite loci were carried out in 10ul PCR reaction containing $2.5 \mathrm{ul}$ of $50 \mathrm{ng} / \mathrm{ul}$ total genomic DNA, $0.5 \mathrm{ul}$ of $5 \mathrm{pMol}$ of forward and reverse primers each, $1.0 \mathrm{ul}$ DMSO, $1.0 \mathrm{ul}$ of $25 \mathrm{mM} \mathrm{mgCl} 2,2.0 \mathrm{ul}$ of $2.5 \mathrm{Mm}$ DNTPs, 13.3ul of $\mathrm{H}_{2} \mathrm{O}$ and $0.2 \mathrm{ul}$ of Taq DNA polymerase using master Mix. Amplification was achieved using Eppendorf thermo cycler. The amplification condition was an initial step of denaturation for 5 minutes at $94^{\circ} \mathrm{C}$ followed by 35 cycles each consisting of denaturation step of 15 seconds at $94^{\circ} \mathrm{C}$, an annealing step of 20 seconds at $55^{\circ} \mathrm{C}$ and an extension step of 30 seconds at $72^{\circ} \mathrm{C}$. Seven minutes will be given after the last cycle of the extension step at $72^{\circ} \mathrm{C}$ to ensure the completion of primer extension reaction followed by cold temperature at $10^{\circ} \mathrm{C}$ lasting for infinity. The PCR products were separated $1.5 \%$ polyacrylamide gel at 80 volts, $300 \mathrm{~mA} 60 \mathrm{~W}$ for 1 hour 30 minutes. It was then visualized and photographed using silver staining under UV trans illuminator (Zang et al., 2002).

\section{Polyacrylamide gel electrophoresis (PAGE)}

The reagent used was prepared from a mixture of the following; 40ml of water, $25 \mathrm{ml}$ of TBE, $7.5 \mathrm{ml}$ of polyacrylamide, $50 \mathrm{ul}$ of terred and $500 \mathrm{ul}$ of APS was added last. The procedure includes the glass comb rubber were washed in order to dry. The glass plate and spacer were wiped with $70 \%$ ethanol. The glass plate was lined with rubber and the spacer was placed between both spacers. The plates were carefully clipped together (the blue clip is used to clip the plate together while the white clip is used to clip the electrophoretic tank). When the glass tank was well arranged and positioned the mixed reagent was poured into it until it gets to the brim. It was then allowed for some minutes to gel after which it was then inserted into the gel tray where the DNA samples were introduced using staining dye alongside the $1 \mathrm{~kb}$ plus ladder gene ruler from thermos-scientific for formation of bands the gels were then brought out after 1hour 30minutes and loaded into the chamber for viewing using the UV trans illuminator.

\section{Statistical Analysis and Molecular Data Analysis}

All data were subjected to Analysis of variance (ANOVA) and difference in mean was separated using DMRT at $95 \%$ probability level $(\mathrm{p}<0.05)$ while the relationship among the quantitative and qualitative traits was established using Pearson correlation co-efficient and principal component Analysis (PCA). In addition, Heritability, Phenotypic Coefficient of Variance (PCV) and Genotypic Coefficient of Variance (GCV) was also determined using SAS version 9.3 software.

Also, Molecular data generated was subjected to molecular analysis in order to generate information on total gene diversity, gene diversity per locus using Pop-Gene version 1.32 (Yeh and Boyle, 1999) and power-maker V3.25 (liu and Muse, 2005). The values obtained were used to generate dendrogram using Unweighted Pair Group Method with Arithmetic Average (UPGMA). Cluster analysis as described by Sneat and Sokal (1973) was estimated to reveal phonetic representation of genetic relationship among the treated Maize genotypes.

Journal of the Faculty of Agriculture and Veterinary Medicine, Imo State University Owerri website: www ajol.info; Attribution:Non- commercial CC BY-NC 


\section{RESULTS}

The analysis of variance showed that growth and yield characters were significant $(\mathrm{p}<0.05)$ across the genotype $(\mathrm{G})$, treatment $(\mathrm{T})$, Week after planting (WAP) and the first order interactions (G x T, G x WAP, Tx WAP), except in dry leaf biomass (DLB) where Treatment (T) and $\mathrm{T} \times \mathrm{W}$ were significant at $\mathrm{p}<0.01$. The results of the second-order interaction $(\mathrm{G} \times \mathrm{T} \times \mathrm{WAP})$ were significant $(\mathrm{p}<001)$ on plant height, leaf length and number of leaves while significance at $\mathrm{p}<0.05$ were recorded in leaf width, dry root biomass (DSB) and dry leaf biomass (DLB). Disease incidence only showed significant $(\mathrm{p}<005)$ results with Treatment, WAP and G x T (Table 2).

Maize genotype DTSR-WCo followed by TZE WDTSTR $\mathrm{C}_{4}$ expressed the most significant ( $\mathrm{p}<0.05)$ performance of plant height $(62.35 \mathrm{~cm}, 59.47 \mathrm{~cm})$, leaf length $(7.55 \mathrm{~cm}, 7.15 \mathrm{~cm})$, leaf width $(62.35 \mathrm{~cm}, 59.47 \mathrm{~cm})$, number of leaves $(3.12 \mathrm{~cm}, 3.02 \mathrm{~cm})$ respectively. The most significant number of tassels was recorded in TZM 132. Genotypes TZL COMP1 $\mathrm{C}_{2}$ and TZM 1318 were the most disease resistant, the two with TZM 140 were least affected by root lodging while the results of disease and root lodging resistance were not significantly different among other genotypes. The genotypes, TZM 132, TZM 1318, TZE WDTSTR $\mathrm{C}_{4}$, TZM 217, DTSR$\mathrm{WC}_{\mathrm{O}}$ and OBA SUPPER $\mathrm{F}_{2}$ recorded the most significant dry shoot biomass, dry leaf biomass (including TZM 1551) and dry root biomass (except OBA SUPPER $F_{2}$ ). DTSR-WCo showed highly significant tassel length $(3.82 \mathrm{~cm})$ while the least significant was recorded in TZM 217 $(0.23 \mathrm{~cm})$ and TZM $1300(0.25 \mathrm{~cm})$ respectively (Table 3$)$.

The performance of growth characters of maize plants subjected to x-ray treatments declined with increasing intensity of the x-ray when compared to the control, at 100Kv/MAS the least plant height $(54.10 \mathrm{~cm})$, leaf length $(54.10 \mathrm{~cm})$ and leaf width $(2.68 \mathrm{~cm})$. However, the highest performances were reported at varying x-ray levels as obtained in the number of leaves $(7.02 \mathrm{~cm}$ at $85 \mathrm{Kv} / \mathrm{MAS})$, number of tassels $(0.86 \mathrm{~cm}$ at $90 \mathrm{Kv} / \mathrm{MAS})$, most resistant disease incidence (1.25 at $90 \& 95 \mathrm{Kv} / \mathrm{MAS})$, and root lodging (0.11 at $95 \mathrm{Kv} / \mathrm{MAS})$. The results of the agronomic characters also showed the most significant performance in dry shoot biomass $(0.52 \mathrm{~g}$ at 100 $\mathrm{Kv} / \mathrm{MAS})$, dry root biomass $(0.02 \mathrm{~g}$ at $85,90 \& 95 \mathrm{Kv} / \mathrm{MAS})$, dry leaf biomass $(0.25 \mathrm{~g}$ at $100 \mathrm{Kv} / \mathrm{MAS})$ and tassel length $(2.21 \mathrm{~cm}$ at $100 \mathrm{Kv} / \mathrm{MAS})$ (Table 4$)$.

\section{Correlation co-efficient among characters of Treated Maize Genotypes}

The result of Table 5 shows that plant height had strong positve correlation with number of leaves $(\mathrm{r}=0.77)$, leaf length $(\mathrm{r}=0.90)$ and leaf width $(\mathrm{r}=0.77)$. but a weak correlation with number of tassels $(\mathrm{r}=0.3413)$, Dry shoot biomass ( $\mathrm{r}=0.16)$, Dry root biomass $(\mathrm{r}=0.17)$ and Dry leaf biomass $(\mathrm{r}=0.16)$. Number of leaves had a positve correlation with leaf length $(\mathrm{r}=0.76)$ and leaf width $(\mathrm{r}=0.76)$. Leaf leangth had a strong positve correlation with leaf width $(\mathrm{r}=0.73)$. Dry shoot biomass had strong positive correlation with dry root biomass $(r=0.87)$ and Dry leaf biomass $(r=0.94)$ while Dry root biomass has strong positive correlation with dry leaf biomass $(r=0.86)$.

Journal of the Faculty of Agriculture and Veterinary Medicine, Imo State University Owerri website: www ajol.info; Attribution:Non- commercial CC BY-NC 


\section{Principal Component Analysis of Growth and Yield Characters of Treated Maize Genotypes.}

The result from Table 6 delinates maize genotypes into 11 principal axis; prin 1, prin 2, prin 3, and prin 4. Prin one which constituted the highest accounted for 0.4168 of the proportion Eigenvalue of 4.5847 while Prin 11 was the least with proportion of 0.0056 and eigenvalue of 0.0056 . Number of leaves from Prin 1 had the highest eigenvector of (0.6932) while dry shoot biomass was the least with (-0.0482). Also, Prin 2 produced highest eigenvector for plant height at (0.4944) while number of tassels produced the least at $(0.1526)$. Prin 3 produced the highest eigenvector at (0.7932) while leaf length produced the least at (-0.2888). Prin 4 produced the highest eigenvector at (0.8164) for number of tassels while tassel length had the least at (-0.4772).

Heritability, Phenotypic and Genotypic Variance of Growth and Yield related characters in treated Maize genotypes

The component of variance for growth and yield analysis in maize genotypes and treated maize genotypes consisting of phenotypic variance, Genotypic variance and heritability are shown in tables 7 . and 8 . The phenotypic variance of both growth and yield character were higher than the genotypic variance in all characters determined. The value of the phenotypic and genotypic variance was highest at leaf lenght with values of 848.4 and 706.82 respectively but least at root lodging with the values of 0.2 and 0.4. the heritability was highest at dry root biomass with the value of 1.0 but least at Disease incident this implies that for leaf width, the proportion of phenotype resulted from the genotype. On table 4.9 the genotypic and phenotypic variances were highest in disease incident at 1112.31 and least in dry root biomass also, the heritabilitywas highest in disease incident and least in dry root biomass.

It was calculated using the following formular:

$$
\begin{gathered}
\text { Genotypic variance. }=\text { Genotypic MS - Error MS } \\
\text { Replicate }
\end{gathered}
$$

Phenotypic variance $=$ Genotypic variance + Error MS

$$
\text { Heritability }=\frac{\text { Genotypic Variance }}{\text { Phenotypic variance }}
$$




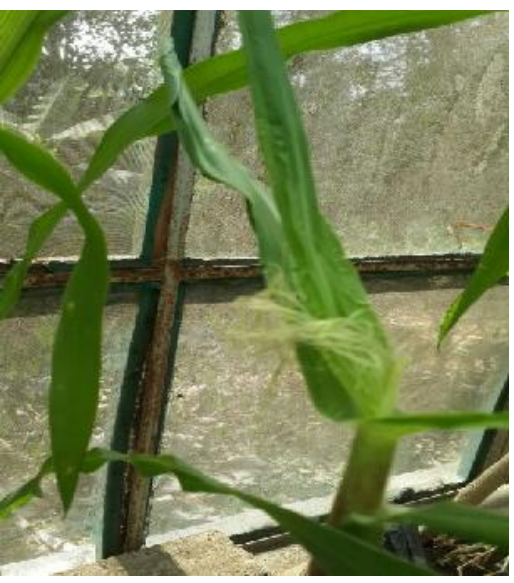

Plate 1: TZL COMP1 C2 at 100Kv/mas of x-ray.

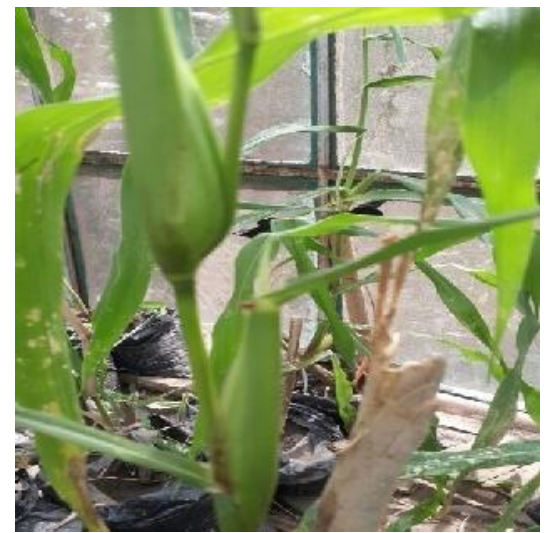

Plate 2: DTSR-WCo at $100 \mathrm{kv} / \mathrm{mas}$ of $\mathrm{x}$-ray.

\section{Nano drop and DNA concentration of Treated Maize Genotypes.}

Table 8 shows Nano-drop and DNA concentration of Treated Maize genotypes. The Nano-drop and DNA concentration for the extracted Maze genotypes were found to be at 260/280/gl. The quantity of genomic concentration was very good generally. However, the genotype TZM 132 with $100 \mathrm{KV} / \mathrm{MAS}$ treatment had the highest DNA quality at $1.91 \mathrm{~g} / \mathrm{ul}$ from the total of 2086.60/ul of genomic DNA extracted. Though genotype TZM 1551 with 0KV/MAS produced the highest concentration at $2841.6 \mathrm{~g} / \mathrm{ul}$ it had a quality of $1.88 \mathrm{~g} / \mathrm{ul}$. The lowest extracted total genomic DNA and concentration was recorded at $188.1 \mathrm{~g} / \mathrm{ul}$ and 1.43 for the genotypes TZM1551.

Frequency, Diversity and Polymorphic Information Content (PIC) of treated Maize Genotypes Using SSR Markers.

A total of eight primers of SSR marker were used to investigate the genetic diversity and molecular relationship of maize germplasm in treatment combinations. The result obtained

Journal of the Faculty of Agriculture and Veterinary Medicine, Imo State University Owerri website: www ajol.info; Attribution:Non- commercial CC BY-NC 
shows that all primers were polymorphic across Maize genotypes with a total of three hundred and seven (307) amplified microsatellite loci, and a total of twenty-three (23) alleles were identified as shown in table 4 . The percentage of allele diversity recorded was $50 \%$ while the polymorphic content information was $43 \%$.

The number of amplified loci and number of alleles range from 23-48 and 2 to 3 with a mean of 38.37 and 2.88. Major allele frequency ranges from 0.47-0.96 with a mean of 0.80 while the allele diversity and polymorphic information content varied from 0.13 to 0.66 and 0.12 to 0.59 with mean of 0.49 and 0.43 respectively.

There were variations in major allele frequency, number of amplified microsatellites loci, number of allele and allele diversity. UMC 2281had the highest number of amplified microsatellite loci at 48 while BMC1755had the least at 23. Also, UMC 1295had the highest major allelic frequency at 0.93 while BMC1755 had the least frequency at 0.39 . Polymorphic Information content was highest in BMC1755 at 0.59 while UMC 1295 had the least at. Gene diversity was observed to be highest in BMC1755 with value of 0.66 and least in UMC 1295with a value of 0.12 (Table 9).

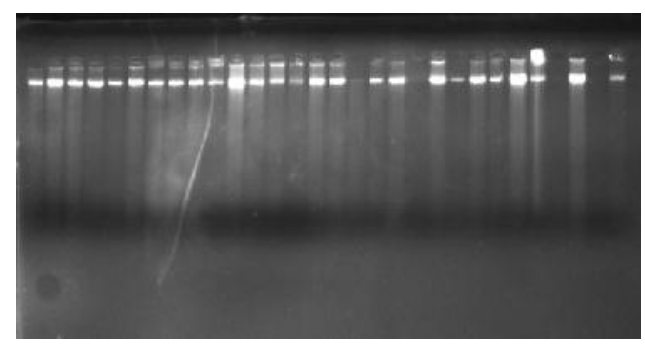

Plate 3: Genomic DNA 1-30

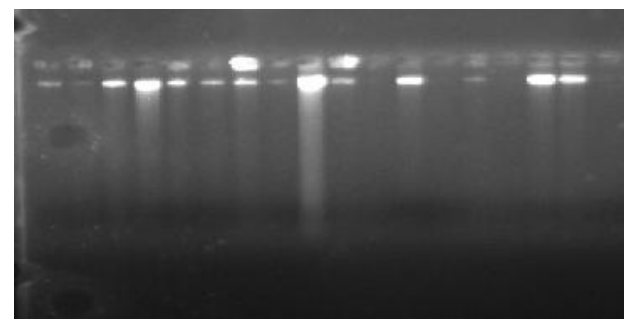

Plate 4 cont'd Genomic DNA 31-48

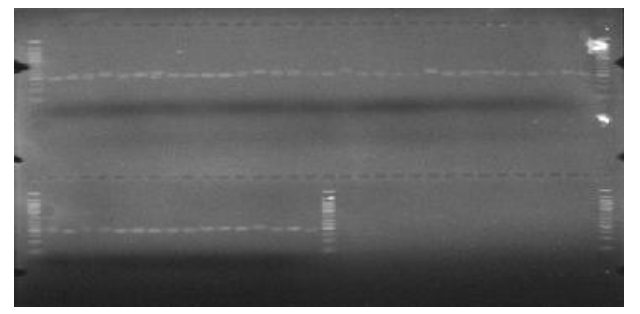

Plate 5: Polymorphic band revealing bmc1520 SSR Primer.

Journal of the Faculty of Agriculture and Veterinary Medicine, Imo State University Owerri website: www ajol.info; Attribution:Non- commercial CC BY-NC 


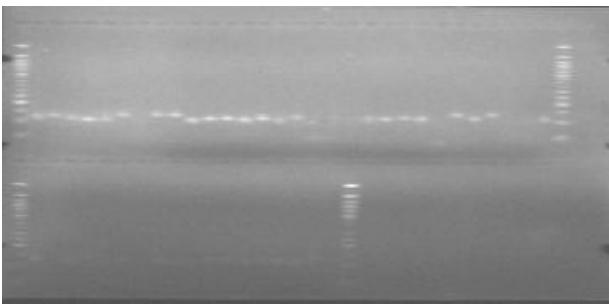

Plate 6: Polymorphic band revealing bmc1755 SSR Primer

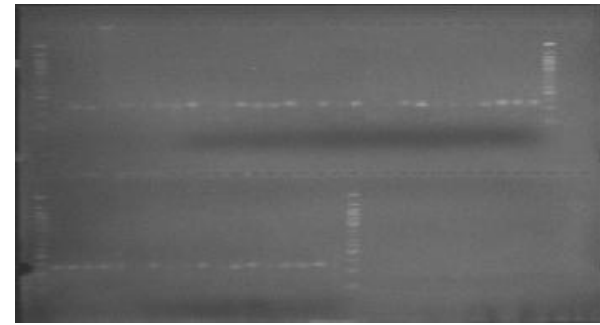

Plate 7: Polymorphic band revealing umc2151 SSR Primer

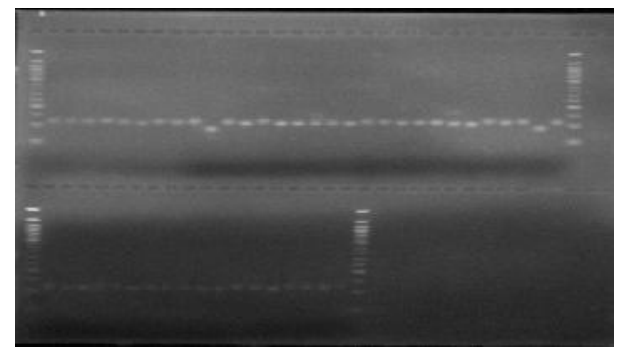

Plate 8: Polymorphic band revealing zct197 SSR Primer

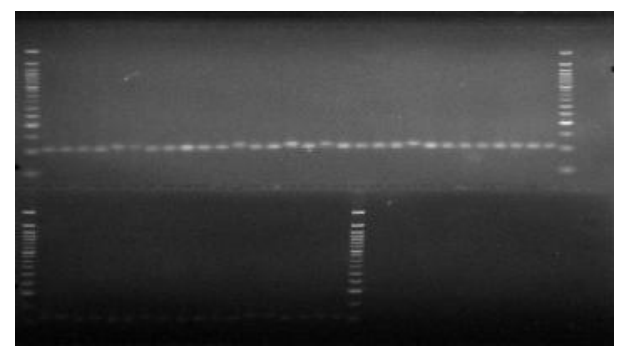

Plate 9: Polymorphic band revealing zmcp7430 SSR Primer

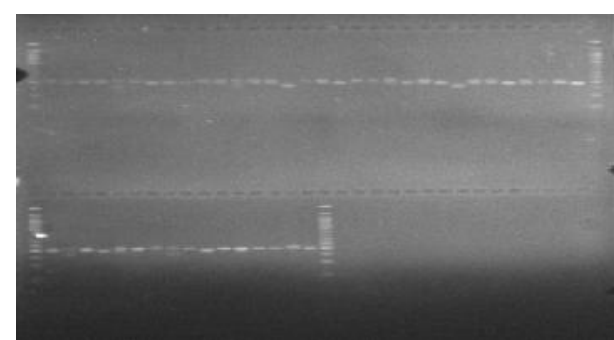

Plate 10: Polymorphic band umc2281 SSR Primer

Journal of the Faculty of Agriculture and Veterinary Medicine, Imo State University Owerri website: www ajol.info; Attribution:Non- commercial CC BY-NC 


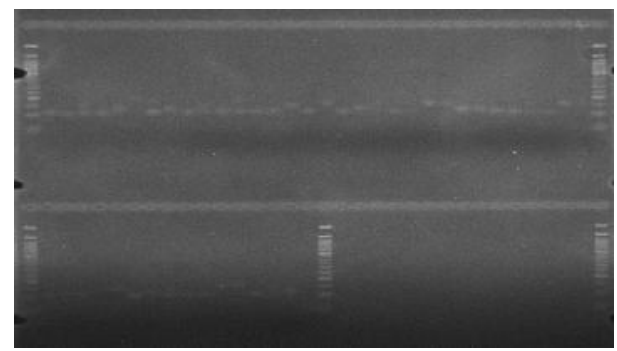

Plate 11 polymorphic band revealing unc1295 SSR primer

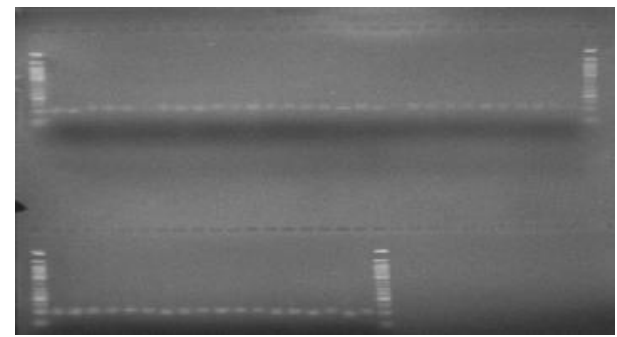

Plate 12 polymorphic band revealing umc1822 SSR primer

\section{Dendrogram Showing the Genetic Similarity among 48 Treated Maize Genotypes}

The Fifty samples comprising of ten (10) genotypes of maize were grouped into six different clusters as shown in figure 2 . The genetic similarity and distances among treated maize genotypes were depicted from the dendrogram. The first cluster comprised of only G2T2 this implies that the second genotype treated with $90 \mathrm{KV} / \mathrm{Mas}$ of X-ray is genetically different from all other treated maize genotypes.

The second cluster comprised of G7T1 G9T4 G10T4 G2T4 G7T4 G7T3 G1T3 G3T4 G4T4 G2T3G5T3 G1T4 G8T3 G4T3 G5T4 G3T3 G6T4 G7T4 G6T3 and G8T4. This implies that all most all the maize genotypes treated with $95 \mathrm{Kv} / \mathrm{Mas}$ and $100 \mathrm{Kv} / \mathrm{mas}$ are genetically similar. The third cluster comprised of G8T1 G9T2 G10T1 G7T2. The fourth cluster comprised of G5T0 G8T0 G9T0 G1T1 G4T1 G6T1 G3T2 G3T1 G2T1 G2T0 G10T0 G3T0 G7T0 G9T1 G8T2 G4T2 G4T0 G10T0 G1T2 G6T2 G5T2 G5T1. This implies that the controlled maize genotypes and those having treatment of $85 \mathrm{kv} / \mathrm{mas}$ and $90 \mathrm{kv} / \mathrm{mas}$ are genetically similar.

The fifth cluster comprised of G10T3 and the sixth cluster comprised of G6T0. This indicates that the tenth genotype treated with $95 \mathrm{kv} / \mathrm{mas}$ and the sixth genotypes with no treatment are genetically different from each other and from genotypes of other clusters (Figure 1).

\section{DISCUSSION}

The options for increasing food production by at least $70 \%$ so as to cope with the rapid increase in human population are limited by the ever-changing climate condition. Induced mutations therefore unmask alleles that can be harnessed to breed superior varieties. In this study, the performance of growth and yield characters of maize which was observed to be significantly Journal of the Faculty of Agriculture and Veterinary Medicine, Imo State University Owerri website: www ajol.info; Attribution:Non- commercial CC BY-NC 
different is an indication of variation. This is in accordance with Bornzoueiet al., (2010), Delia et al., (2013) and Olawuyiet al., (2016) who considered genetic variation as essential for crop improvement. The genotypic and treatment reveal significant effect on the growth performance of Maize this may be attributed to genetic difference in growing types and difference on the type of adaptation.

DTSR-WCo showed higher tolerance to the mutagenic effect of $\mathrm{x}$-ray radiation with respect to plant height, leaf length, number of leaves, leaf width, length of tassels and dry leaf biomass compared to TZL COMP1 $\mathrm{C}_{2}$ which could not tolerate the varied exposure periods. Also, with respect to dry shoot biomass and dry root biomass TZM 1318 and TZM 132 expressed tolerance to mutagenic effect of $\mathrm{X}$-ray radiation.

X-ray imposed significant impact on most of the characters studied. The highest plant height was observed at $85 \mathrm{~kg}$. By increasing radiation dose to 90,95 , and $100 \mathrm{Kv} / \mathrm{mas}$ plant height declined by $26.5 \%, 27.9 \%$ and $27.0 \%$ respectively. The symptoms commonly observed in low dose irradiated are inhibition of germination, seedling growth, and other biological responses are associated with low dose radiation. Kim et al., (2000) also reported that there are hypothesis that low dose irradiation could induce the growth stimulation by changing the hormonal signaling network in plant cell or by increasing the anti-oxidative capacity to easily overcome daily stress factors such as fluctuation of light intensity and temperature in the growth condition whereas high dose irradiation which resulted to growth inhibition is ascribed to cell cycle arrest at G2/M phase during somatic cell division and or various damages in the entire genome (Preusa and Britta, 2009).

It was also observed that X-radiation increased significantly the dry shoot biomass and dry root biomass. Seeds irradiated with $100 \mathrm{kv} / \mathrm{mas}$ had significantly higher root weight. This agrees with the findings of Melki and Salami (2008) who observed that gamma rays (15 Gy) induced significant improvement on plant dry weight in chicken pea compared with control dose. Number of tassels and length of tassels were observed to be significantly higher at 90 and 100 $\mathrm{kv} / \mathrm{mas}$ respectively.

Finding s from correlation analysis shows that the growth characters (plant height, leaf length, leaf width, and number of leaves) exhibited strong positive relationship with one another while the yield characters (dry shoot biomass and dry root biomass) exhibited strong positive relationship with each other but weak relationship with the growth-related characters. These findings are in accordance with the report of Olawuyiet al., (2012). This implies that selection for any of the growth characters will probably not favor the yield characters.

The Principal Component Analysis shows that there is variation among the characters studied and the grouping of various characters into components in which prin 1 accounted for the highest eigen vector and proportion. Similar observation was also made by Olawuyiet al., (2012) and Olawuyi and Onuoha, (2017). The scatter plot also shows that plant height and leaf length are 
more closely related with each other. However, leaf width and number of leaves expressed distant relationship between themselves and other characters evaluated in this study. The yield related characters were found to be closely related to each other. These differences and similarities observed among the character evaluated in this study may be due to the difference or similarities in the genes controlling the characters.

Heritability is the proportion of phenotypic variance that is due to genetic variance (Ogunniyanet al., 2014). In this study heritability was greater than 70\%. This implies that environmental influence was minimal on the characters studied and these characters can therefore be used for selection. This result was consistent with the findings of Galapiaet al., (2012); Akbar et al., (2008); Rafi et al., (2010).

TZM 132 at 100kv/mas of x-ray had the highest concentration of extracted DNA while TZM 1551 at $0 \mathrm{kv} / \mathrm{mas}$ had the highest genomic DNA nanodrop. This implies that good quality DNA is obtained when Maize genotype was treated with 100kv/mas of x-ray.

Among noteable molecular markers used for genetic diversity studies maker assisted selctions is SSR maker (Zhao et al., 2011). Short repeated sequence are widely found in genome and shows great variation making them very usefull markers (Robert, 2013). All the primers used in this study were polymorphic across the the treated maize genotypes. However, the average polymorphic informaton contents was found to be below $50 \%$ this could be due to the effect of x-rays. There were also variations in major allele frequency, number of amplified microsatellite loci and number of allele and allele diversity. This information can assist breeders in selecting the appropriate breeding method to be applied to maize so as to obtain maximum yield and also maintain genetic variability.

Cluster analysis and dendrogram indicate that cluster group consist of genotypes from different treatment combination. The cluster diagram among treated Maize genotype shows that there genetic similarities and differences among treated maize genotypes. In the diagram it was observed that X-ray radiation of $85 \mathrm{KV} / \mathrm{ma}, 90 \mathrm{KV} / \mathrm{ma}$ and $0 \mathrm{KV} / \mathrm{ma}$ had similar effect on maize genotypes as most of the genotypes treated with these doses were grouped into the same cluster. Also $95 \mathrm{KV} / \mathrm{mas}$ and $100 \mathrm{KV} / \mathrm{mas}$ had similar effect as they were grouped into the same cluster as well. This implies that low dose X-ray is sufficient to induce genetic variability in maize plant.

\section{CONCLUSION AND RECOMMENDATION}

Genotype DTSR-WCo performed best for growth and yield and could therefore be selected for improvement of other maize genotypes.

Primer BMC1755 detected the highest polymorphic information contents compared to other primers. Hence, this primer could be subsequently used for mutagenic breeding of maize and other cereals. 


\section{REFERENCES}

Adeosun, F. and Olawuyi, O. (2019). Maize germplasm evaluation in Ibadan Nigeria. Journal of Agriculture and veterinary science 12(1)34-40.

Akbar, M., Saleem, M., Muhammad, F., Ashraf, M., Ahmad, R. (2008). Combining ability analysis in maize under normal and high temperature conditions. Pakistan Journal of Agricultural Research. 3(2):218-227.

Borzouei, A., Kafi, M., Khazaei, H., Naseriyan, B., Majdabadi, A. (2010). Effects of Gamma Radiation on Germination and Physiological Aspects of Wheat (Triticum aestivumL.) seedlings. Pakistan Journal of Botany. 42(4), 2281-2290.

Chengzhi, L. (2011). Agronomy in Space China's Crop Breeding Program. Space Policy. 27:157-164. https://doi.org/10.1016/j.spacepol.2011.06.001

Delia, J., Cisneros-Heredia, D., Whitney, J. and Murrieta-Galindo, R. (2010). Observations on the reproductive behavior of a Neotropical glassfrog, Hyalinobatrachiumfleischmanni (Anura: Centrolenidae). South American Journal of Herpetology. 5(1): 1-12. https://doi.org/10.2994/057.005.0101

Dwivedi, A., Singh, A., Kumar, V., Naresh, R., Tomar, S., and Dev, I. (2016). Population studies, phenology and quality of mashbean and maize as influenced by planting geometry and nutrient management under intercropping system. Progressive Agriculture. 15(1): 95-98. https://doi.org/10.5958/0976- 4615.2015.00010.1

Eze, J.J. and Dambo, A. (2015). Mutagenic effects of sodium azide on the quality of maize seeds. Journal of Advanced Labouratory Research. 5(1).

Galapia, G.A., Carandang W.M., Vallesteros S.F. and Vallesteros, A.P. (2012). Heritability of and relationship among selected seed traits of three provenances of Jatropha curcas L.,Forest Science and Technology,8:3,139-144, DOI:10.1080/21580103.2012.704967.

Griffiths, A. (2005). An introduction to genetic analysis. Macmillan.

Guo, H., Jin, W., andZhao, L. (2010). Mutagenic effects of different factors in spaceflight environmentof Shijian-8 satellite in wheat. Acta Agron. Sin. 36:764-770. https://doi.org/10.3724/SP.J.1006.2010.00764

Gupta, V., and Raj, H. (1999). A note on effect of zinc application on the yield and phosphorus nutrition of coriander. Haryana Journal of Horticultural Sciences 9(12):82-83.

Kim, B., Yu, S., Tak, S., Hoon, Y., Won Y., Song K., and Won, S. (2012). A Study on the Plants for Phenology of the Mt. Palgongsan Provincial Park. Journal of Korean Nature. 5(4): 287-292. https://doi.org/10.7229/jkn.2012.5.4.287 
Melki, M., and Sallami, D. (2008). Studies the effects of low dose of gamma rays on the behaviour of chickpea under various conditions. Pakistan Journal of Biological Sciences 11(19): 2326-2330. https://doi.org/10.3923/pjbs.2008.2326.2330

Ogunniyan, D., and Olakojo, S. (2014). Genetic variability of agronomic traits of low nitrogen tolerant open-pollinated maize accessions as parents for top-cross hybrids. Journal of Agriculture and Sustainability6(2).

Olawuyi, O., Bello, O., Ntube, C., and Akanmu, A. (2015). Progress from selection of some maize cultivars' response to drought in the derived savanna of Nigeria. Agrivita 37(1), 8. https://doi.org/10.17503/Agrivita-2015-37-1-p008-017

Olawuyi, O., Odebode, A., and Olakojo, S. (2013). Genotypex treatment× concentration interaction and character association of maize (Zea mays L.) under arbuscular mycorrhiza fungi and Striga lutea Lour. Proceedings of the 37th Annual Conference of the Genetics Society of Nigeria pp. 210-219

Olawuyi, O. and Onuoha, S. (2017). Genetic Assessment of Amaranthus Linn. Genotypes in Treatment Combinations of Glomus clarum and Leucaena leucocephala Lam. Using Simple Sequence Repeat (SSR) Marker. Molecular plant breeding. 8(1). https://doi.org/10.5376/mpb.2017.08.0010

Sneath, P., and Sokal, R. (1973). Numerical taxonomy. The principles and practice of numerical classification. San Francisco Freeman, 573p. Available from: http://garfield.library.upenn.edu/classics1987/A1987F272200002.pdf (Last accessed $11 / 11 / 2020)$

Xing, Y. (2011). Prediction of nucleosome occupancy in Saccharomyces cerevisiae using position-correlation scoring function. Genomics 98(5):359-66. https://doi.org/10.1016/j.ygeno.2011.07.008

Zhang, Y., Yu, Z., Fu, X., and Liang, C. (2002). Noc3p, a b HLH protein, plays an integral role in the initiation of DNA replication in budding yeast. Cell 109(7): 849-860. https://doi.org/10.1016/S0092-8674(02)00805-X 
Journal of Agriculture and Food Sciences

Odunayo J. Olawuyi, David F. Igata, 16

Volume 18, Number 2, October 2020, pp 1- 25

Akinlolu O. Akanmu, \& Abeeb A. Azeez

\section{APPENDIX}

The simple sequence repeat primers and their oligonucleotide sequences are shown in Table 1 .

\begin{tabular}{lll}
\hline SSR PRIMER & Direction & OLIGONUCLEOTIDE SEQUENCE \\
\hline umc2151 & Forward & ATATGGTATTTCTGCAGGCGT \\
& Reverse & AAAATCCTATACAGAAAACGGGCG \\
bmc1755 & Forward & TGCGCACCAGCGACTGACC \\
& Reverse & GCGGGCGACGCTTCCAAAC \\
zct197 & Forward & GCGAGAAGAAAGCGAGCAGA \\
& Reverse & CGCCAAGAAGAAACACACATCACA \\
zmcp7430 & Forward & CGAAGCTGCTGTAAGTTTTCG \\
& Reverse & AAGACTTCTCGGCTCTTATCCA \\
bmc1520 & Forward & TCCTCTTGCTGGATGTCC \\
& Reverse & ACAGCTGCGTAGCTTCTTCC \\
umc1295 & Forward & GTCGATCTTCCTCCCCATCA \\
& Reverse & CGTTTCTATCTATGGAGTGCG \\
& Forward & CAATGATTGGAGCCTAACCCCT \\
& Reverse & ATGATGATCTGCAGAGCCTAGTCC \\
& Forward 281 & CGAAGCTGCTGTAAGTTTTCG \\
& & AAGACTTCTCGGCTCTTATCCA \\
\hline
\end{tabular}

Journal of the Faculty of Agriculture and Veterinary Medicine, Imo State University Owerri website: www ajol.info; Attribution:Non- commercial CC BY-NC 
Odunayo J. Olawuyi, David F. Igata, 17 Volume 18, Number 2, October 2020, pp 1-25.

Table 2:Mean Square Variance of Growth and Yield related Characters at different stages in Maize Genotypes

\begin{tabular}{|c|c|c|c|c|c|c|c|c|c|c|c|c|}
\hline Source of Variation & df & PH (cm) & $\mathbf{L L}(\mathbf{c m})$ & $\mathbf{L W}(\mathbf{c m})$ & $\mathbf{N L}$ & NT & $\mathbf{L T}(\mathbf{c m})$ & DSB (g) & DRB (g) & DLB (g) & DI & $\mathbf{R L}$ \\
\hline Genotype (G) & 9 & $2353.66^{* *}$ & $2968.86^{* *}$ & $36.29 * *$ & $37.66 * *$ & $40.41 * *$ & $232.26 * *$ & $4.88 * *$ & $0.01 * *$ & $0.94 * *$ & $87.24 \mathrm{~ns}$ & $0.32 *$ \\
\hline Treatment (T) & 4 & $2370.68 * *$ & $4100.24 * *$ & $4.78 * *$ & $46.82 * *$ & $9.74 * *$ & $102.76 * *$ & $3.71 * *$ & $0.01 * *$ & $0.20 *$ & $4503.40 * *$ & $0.53 *$ \\
\hline WAP (W) & 9 & $98613.34 * *$ & $99979.04 * *$ & $218.18^{* *}$ & $947.97 * *$ & $61.84 * *$ & $630.77 * *$ & $260.03 * *$ & $0.80 * *$ & $63.83 * *$ & $38006.82 * *$ & $60.59 * * *$ \\
\hline Replicate (R) & 3 & $2101.62 * *$ & $959.79 * *$ & $23.73 * *$ & $59.01 * *$ & $14.79 * *$ & $13.03^{\mathrm{ns}}$ & $1.61 *$ & $0.014 * *$ & $0.69 * *$ & $279.68 *$ & $0.19^{\text {ns }}$ \\
\hline $\mathrm{G} \times \mathrm{T}$ & 35 & $946.26^{* *}$ & $1273.02 * *$ & $14.73 * *$ & $10.22 * *$ & $9.59 * *$ & $43.36 * *$ & $1.63 * *$ & $0.00 * *$ & $0.40 * *$ & $182.78 * *$ & $0.29 *$ \\
\hline $\mathrm{G} \times \mathrm{WAP}$ & 81 & $261.48 * *$ & $283.09 * *$ & $1.77 * *$ & $2.28 * *$ & $3.96 * *$ & $37.48 * *$ & $2.04 * *$ & $0.01 * *$ & $0.34 * *$ & $88.13^{\mathrm{ns}}$ & $0.32 * * *$ \\
\hline $\mathrm{T} \times \mathrm{WAP}$ & 36 & $416.43 * *$ & $585.26^{* *}$ & $2.08 * *$ & $5.58 * *$ & $0.91 \mathrm{~ns}$ & $16.45^{* *}$ & $2.16^{* *}$ & $0.01 * *$ & $0.10^{*}$ & $4519.27^{\mathrm{ns}}$ & $56 * * *$ \\
\hline $\mathrm{G} \times \mathrm{T} \times \mathrm{WAP}$ & 311 & $158.59 *$ & $172.71 *$ & $1.21 * *$ & $1.28 *$ & $1.01^{\mathrm{ns}}$ & $6.97^{\mathrm{ns}}$ & $0.99 * *$ & $0.00 * *$ & $0.23 * *$ & $182.9^{\mathrm{ns}}$ & $0.29 * * *$ \\
\hline Error & 852 & 124.98 & 141.58 & 0.63 & 1.1 & 1.02 & 6.27 & 0.36 & 0 & 0.06 & $54.17^{\mathrm{ns}}$ & 0.16 \\
\hline Corrected Total & 1860 & & & & & & & & & & & \\
\hline
\end{tabular}

$*=$ Significant at $\mathrm{P}<0.05, * *=$ highly significant at $\mathrm{P}<0.01, \mathrm{df}=$ degrees of freedom.

PH - Plant height, LL - Leaf length, NL- Number of leaves, NT- Number of tassels, LT- length of tassel, DSB- dry shoot biomass (g), DRB - dry root biomass (g), DLB - dry leaf biomass, DI - disease incident, RL-root length, WAP- Week After Planting 


\section{Table 3: Genotypic effect of growth and yield characters at different stages of treated maize genotypes}

\begin{tabular}{|c|c|c|c|c|c|c|c|c|c|c|c|}
\hline Genotypes & $\begin{array}{l}\text { Plant } \\
\text { height } \\
\text { (cm) }\end{array}$ & $\begin{array}{l}\text { Leaf } \\
\text { Length } \\
(\mathrm{cm})\end{array}$ & $\begin{array}{l}\text { Leaf Width } \\
(\mathrm{cm})\end{array}$ & $\begin{array}{l}\text { Number } \\
\text { of Leaves }\end{array}$ & $\begin{array}{l}\text { Number } \\
\text { of Tassels }\end{array}$ & $\begin{array}{l}\text { Disease } \\
\text { Incidence }\end{array}$ & $\begin{array}{l}\text { Root } \\
\text { Lodging }\end{array}$ & $\begin{array}{l}\text { Dry Shoot } \\
\text { Biomass (g) }\end{array}$ & $\begin{array}{l}\text { Dry root } \\
\text { Biomass (g) }\end{array}$ & $\begin{array}{l}\text { Dry Leaf } \\
\text { Biomass (g) }\end{array}$ & $\begin{array}{l}\text { Tassel } \\
\text { Length } \\
\text { (cm) }\end{array}$ \\
\hline TZM 1551 & $50.66^{\mathrm{g}}$ & $6.29^{\mathrm{d}}$ & $50.66^{\mathrm{f}}$ & $2.46^{\mathrm{d}}$ & $0.49^{c}$ & $4.73^{\mathrm{ab}}$ & $0.18^{\mathrm{ab}}$ & $0.32^{\mathrm{bcd}}$ & $0.02^{\mathrm{d}}$ & $0.19^{\mathrm{ab}}$ & $0.81^{\mathrm{e}}$ \\
\hline TZL COMP1 $\mathrm{C}_{2}$ & $50.44^{\mathrm{g}}$ & $5.86^{\mathrm{e}}$ & $50.44^{\mathrm{f}}$ & $1.71^{\mathrm{a}}$ & $0.22^{\mathrm{d}}$ & $3.48^{\mathrm{b}}$ & $0.12^{\mathrm{b}}$ & $0.27^{\mathrm{d}}$ & $0.02^{\mathrm{cd}}$ & $0.17^{\mathrm{bc}}$ & $1.14^{\mathrm{bcd}}$ \\
\hline TZM 132 & $59.04^{\mathrm{bc}}$ & $6.95^{\mathrm{b}}$ & $60.62^{\mathrm{ab}}$ & $2.76^{\mathrm{e}}$ & $0.37^{\mathrm{a}}$ & $5.23^{\mathrm{a}}$ & $0.16^{\mathrm{ab}}$ & $0.48^{\mathrm{a}}$ & $0.02^{\mathrm{abcd}}$ & $0.22^{\mathrm{ab}}$ & $1.54^{\mathrm{bc}}$ \\
\hline TZM 1318 & $59.93^{\mathrm{bc}}$ & $7.03^{\mathrm{b}}$ & $58.93^{\mathrm{bc}}$ & $2.93^{\mathrm{b}}$ & $0.99^{\mathrm{b}}$ & $4.19^{\mathrm{ab}}$ & $0.14^{\mathrm{b}}$ & $0.45^{\mathrm{ab}}$ & $0.03^{\mathrm{a}}$ & $0.23^{\mathrm{ab}}$ & $2.02^{\mathrm{b}}$ \\
\hline 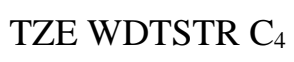 & $59.47^{\mathrm{b}}$ & $7.15^{\mathrm{b}}$ & $59.47^{\mathrm{b}}$ & $3.02^{\mathrm{ab}}$ & $0.56^{\mathrm{c}}$ & $4.92^{\mathrm{ab}}$ & $0.20^{\mathrm{ab}}$ & $0.45^{\mathrm{ab}}$ & $0.02^{\mathrm{abc}}$ & $0.24^{\mathrm{a}}$ & $1.67^{\mathrm{bc}}$ \\
\hline OBA SUPPER $F_{2}$ & $56.63^{\mathrm{cd}}$ & $6.71^{\mathrm{c}}$ & $56.63^{\mathrm{cd}}$ & $2.93^{b}$ & $0.93^{\mathrm{b}}$ & $5.03^{\mathrm{ab}}$ & $0.24^{\mathrm{a}}$ & $0.38^{\mathrm{abcd}}$ & $0.02^{\mathrm{cd}}$ & $0.19^{\mathrm{ab}}$ & $1.40^{\mathrm{cd}}$ \\
\hline TZM 217 & $53.51^{\mathrm{ef}}$ & $6.54^{\mathrm{c}}$ & $53.51^{\mathrm{e}}$ & $2.89^{\mathrm{bc}}$ & $0.19^{\mathrm{d}}$ & $4.11^{\mathrm{ab}}$ & $0.16^{\mathrm{ab}}$ & $0.43^{\mathrm{abc}}$ & $0.02^{\mathrm{abc}}$ & $0.23^{\mathrm{ab}}$ & $0.23^{\mathrm{f}}$ \\
\hline TZM 1300 & $51.62^{g f}$ & $6.57^{\mathrm{c}}$ & $50.53^{\mathrm{f}}$ & $2.40^{\mathrm{d}}$ & $0.03^{\mathrm{d}}$ & $3.44^{\mathrm{b}}$ & $0.18^{\mathrm{ab}}$ & $0.27^{\mathrm{d}}$ & $0.02^{\text {cd }}$ & $0.13^{\mathrm{c}}$ & $0.25^{\mathrm{f}}$ \\
\hline DTSR-WC & $62.35^{\mathrm{a}}$ & $7.55^{\mathrm{a}}$ & $62.35^{\mathrm{a}}$ & $3.15^{\mathrm{a}}$ & $1.01^{\mathrm{b}}$ & $4.84^{\mathrm{ab}}$ & $0.24^{\mathrm{a}}$ & $0.46^{\mathrm{ab}}$ & $0.03^{\mathrm{ab}}$ & $0.24^{\mathrm{a}}$ & $3.82^{\mathrm{a}}$ \\
\hline TZM 140 & $54.80^{\mathrm{de}}$ & $6.32^{\mathrm{d}}$ & $54.80^{\mathrm{de}}$ & $2.53^{\mathrm{d}}$ & $0.21^{\mathrm{d}}$ & $3.58^{\mathrm{ab}}$ & $0.15^{\mathrm{b}}$ & $0.30^{\mathrm{cd}}$ & $0.020^{\text {bcd }}$ & $0.19^{\mathrm{ab}}$ & $0.89^{\mathrm{de}}$ \\
\hline
\end{tabular}

Mean with same letter in the same column are not significantly different from each other at $(\mathrm{P}<0.05)$ according to Duncan Multiple range Test. (DMRT). 
Table 4: Effects of X-ray on the growth and yield characters of maize.

\begin{tabular}{|c|c|c|c|c|c|c|c|c|c|c|c|}
\hline Treatment & $\begin{array}{l}\text { Plant } \\
\text { height } \\
(\mathrm{cm})\end{array}$ & $\begin{array}{l}\text { Leaf } \\
\text { Length } \\
(\mathrm{cm})\end{array}$ & $\begin{array}{l}\text { Leaf } \\
\text { Width } \\
(\mathrm{cm})\end{array}$ & $\begin{array}{l}\text { Number } \\
\text { of } \\
\text { Leaves }\end{array}$ & $\begin{array}{l}\text { Number } \\
\text { of } \\
\text { Tassels }\end{array}$ & $\begin{array}{l}\text { Disease } \\
\text { Incident }\end{array}$ & $\begin{array}{l}\text { Root } \\
\text { Lodging }\end{array}$ & $\begin{array}{l}\text { Dry Shoot } \\
\text { Biomass } \\
\text { (g) }\end{array}$ & $\begin{array}{l}\text { Dry root } \\
\text { Biomass } \\
\text { (g) }\end{array}$ & $\begin{array}{l}\text { Dry Leaf } \\
\text { Biomass } \\
\text { (g) }\end{array}$ & $\begin{array}{l}\text { Tassel } \\
\text { Length } \\
(\mathrm{cm})\end{array}$ \\
\hline 85KV/MAS & $56.37^{\mathrm{b}}$ & $55.92^{\mathrm{b}}$ & $2.59^{\mathrm{b}}$ & $6.19^{c}$ & $0.43^{\mathrm{c}}$ & $7.74^{\mathrm{a}}$ & $0.18^{a}$ & $0.33^{\mathrm{b}}$ & $0.02^{\mathrm{c}}$ & $0.16^{\mathrm{b}}$ & $0.86^{\mathrm{c}}$ \\
\hline 90KV/MAS & $54.25^{\mathrm{c}}$ & $54.10^{\mathrm{c}}$ & $2.59^{\mathrm{b}}$ & $6.88^{\mathrm{a}}$ & $0.86^{\mathrm{a}}$ & $1.25^{\mathrm{c}}$ & $0.18^{a}$ & $0.39^{\mathrm{b}}$ & $0.02^{\mathrm{c}}$ & $0.24^{\mathrm{a}}$ & $0.96^{\mathrm{c}}$ \\
\hline $95 \mathrm{Kv} / \mathrm{Mas}$ & $53.87^{\mathrm{c}}$ & $53.87^{\mathrm{c}}$ & $2.89^{\mathrm{a}}$ & $6.90^{\mathrm{a}}$ & $0.58^{\mathrm{bc}}$ & $1.25^{\mathrm{c}}$ & $0.11^{\mathrm{b}}$ & $0.34^{\mathrm{b}}$ & $0.02^{\mathrm{c}}$ & $0.19^{\mathrm{b}}$ & $1.42^{\mathrm{b}}$ \\
\hline $100 \mathrm{Kv} / \mathrm{MAS}$ & $54.10^{\mathrm{c}}$ & $54.10^{\mathrm{c}}$ & $2.68^{b}$ & $7.02^{\mathrm{a}}$ & $0.56^{\mathrm{bc}}$ & $2.84^{\mathrm{b}}$ & $0.21^{\mathrm{a}}$ & $0.52^{\mathrm{a}}$ & $0.023^{\mathrm{ab}}$ & $0.25^{\mathrm{a}}$ & $2.21^{\mathrm{a}}$ \\
\hline $0 \mathrm{KV} / \mathrm{Mas}$ & $61.42^{\mathrm{a}}$ & $62.31^{\mathrm{a}}$ & $2.65^{\mathrm{b}}$ & $6.60^{\mathrm{b}}$ & $0.59^{\mathrm{b}}$ & $8.25^{\mathrm{a}}$ & $0.20^{\mathrm{ab}}$ & $0.33^{b}$ & $0.025^{\mathrm{a}}$ & $0.17^{\mathrm{b}}$ & $1.37^{b}$ \\
\hline
\end{tabular}

Mean with the same letter in the same column are not significantly different from each other at $(\mathrm{P}<0.05)$ according to Duncan multiple range test.(DMRT) 


\section{Table 5: Correlation co-effeicient among characters of treated Maize Genotypes}

\begin{tabular}{|c|c|c|c|c|c|c|c|c|c|c|c|c|c|c|}
\hline $\begin{array}{l}\text { Char } \\
\text { acter }\end{array}$ & $\begin{array}{l}\text { Plant } \\
\text { Height } \\
(\mathrm{cm})\end{array}$ & $\begin{array}{l}\text { Number } \\
\text { of Leaf }\end{array}$ & $\begin{array}{l}\text { Leaf } \\
\text { Length } \\
(\mathrm{cm})\end{array}$ & $\begin{array}{l}\text { Leaf } \\
\text { Width } \\
\text { (cm) }\end{array}$ & $\begin{array}{l}\text { Number } \\
\text { of } \\
\text { Tassels }\end{array}$ & $\begin{array}{l}\text { Disease } \\
\text { Incidence }\end{array}$ & $\begin{array}{l}\text { Root } \\
\text { Lodging }\end{array}$ & $\begin{array}{l}\text { Dry } \\
\text { Shoot } \\
\text { Biomass } \\
\text { (g) } \\
\end{array}$ & $\begin{array}{l}\text { Dry } \\
\text { Root } \\
\text { Biomass } \\
\text { (g) } \\
\end{array}$ & $\begin{array}{l}\text { Dry Leaf } \\
\text { Biomass (g) }\end{array}$ & $\begin{array}{l}\text { Length of } \\
\text { tassels }(\mathrm{cm})\end{array}$ & $\begin{array}{c}f \text { Geno } \\
\text { type }\end{array}$ & $\begin{array}{l}\text { Treat } \\
\text { ment }\end{array}$ & Week \\
\hline \multicolumn{15}{|l|}{$\mathrm{PH}$} \\
\hline NL & $0.77 * *$ & & & & & & & & & & & & & \\
\hline LL & $0.90 * *$ & $0.76^{* *}$ & & & & & & & & & & & & \\
\hline LW & $0.76^{* *}$ & $0.77 * *$ & 0.73 & & & & & & & & & & & \\
\hline NT & 0.34 & 0.27 & 0.27 & 0.29 & & & & & & & & & & \\
\hline DI & 0.16 & 0.13 & 0.14 & 0.11 & -0.07 & & & & & & & & & \\
\hline RL & 0.15 & 0.14 & 0.15 & 0.15 & -0.08 & 0.06 & & & & & & & & \\
\hline DSB & 0.16 & 0.16 & 0.15 & 0.15 & -0.08 & $0.63 * *$ & $0.73 * *$ & & & & & & & \\
\hline DRB & 0.17 & 0.14 & 0.16 & 0.16 & -0.08 & $0.73 * *$ & $0.74 * *$ & $0.87 * *$ & & & & & & \\
\hline DLB & 0.16 & 0.16 & 0.16 & 0.16 & -0.09 & $0.66^{* *}$ & $0.76^{* *}$ & $0.90 * *$ & $0.86 * *$ & & & & & \\
\hline $\mathrm{TL}$ & 0.33 & 0.32 & 0.33 & 0.33 & 0.02 & 0.00 & 0.00 & 0.02 & 0.01 & 0.01 & & & & \\
\hline $\begin{array}{l}\text { Genot } \\
\text { ypes }\end{array}$ & 0.02 & 0.01 & 0.02 & 0.02 & 0.08 & -0.08 & 0.01 & -0.01 & 0.01 & -0.01 & 0.03 & & & \\
\hline $\begin{array}{l}\text { Treat } \\
\text { ment }\end{array}$ & 0.06 & 0.08 & 0.07 & 0.07 & 0.03 & 0.03 & 0.03 & 0.04 & 0.06 & 0.03 & 0.09 & 0.03 & & \\
\hline Week & $0.79 * *$ & $0.80 * *$ & $0.79 * *$ & $0.79 * *$ & 0.02 & 0.33 & 0.36 & 0.37 & 0.38 & 0.39 & 0.28 & 0.00 & 0.03 & \\
\hline $\begin{array}{l}\text { Repli } \\
\text { cate }\end{array}$ & -0.05 & -0.14 & -0.049 & -0.05 & -0.02 & 0.04 & -0.01 & 0.03 & -0.02 & -0.04 & 0.03 & 0.00 & 0.01 & -0.04 \\
\hline
\end{tabular}

PH: Plant Height; NL: Number of Leaves; LL: Leaves length; LW: Leaf Width; NT: Number of Tassels; DI: Disease Incident; RL: Root Lodging; DSB: Dry

Shoot Biomass; DRB: Dry Root Biomass; DSB: Dry Leaf Biomass; TL: Tassel Length; G: Genotype; T: Treatment; W: Weeks; R: Replicates 
Table 6: Principal Components Analysis (PCA) of Growth and Yield Characters of Treated Maize Genotypes

\begin{tabular}{ccccc}
\hline CHARACTER & PRIN 1 & PRIN 2 & PRIN 3 & PRIN 4 \\
\hline PH & -0.03 & 0.49 & -0.21 & 0.16 \\
NL & 0.69 & 0.30 & -0.06 & -0.25 \\
LL & 0.05 & 0.46 & -0.29 & 0.01 \\
LW & -0.67 & 0.38 & -0.02 & -0.12 \\
NT & 0.11 & 0.15 & 0.49 & 0.82 \\
DI & 0.22 & 0.19 & -0.03 & 0.04 \\
RL & 0.05 & 0.20 & 0.01 & 0.02 \\
DSB & -0.05 & 0.23 & 0.04 & 0.00 \\
DRB & -0.03 & 0.24 & 0.01 & 0.03 \\
DLB & -0.04 & 0.23 & 0.03 & -0.01 \\
TL & 0.00 & 0.22 & 0.79 & -0.48 \\
Eigenvalue & 4.58 & 1.85 & 0.93 & 0.90 \\
Proportion & 0.42 & 0.17 & 0.08 & 0.08 \\
\hline
\end{tabular}

PH: Plant Height; NL: Number of Leaves; LL: Leaves length; LW: Leaf Width; NT: Number of Tassels; DI: Disease Incident; RL: Root Lodging; DSB: Dry Shoot Biomass; DRB: Dry Root Biomass; DSB: Dry Leaf Biomass; TL: Tassel Length; 
Table 7:Heritability, Phenotypic and Genotypic Variance on Growth and Yield Characters in Maize Genotypes

\begin{tabular}{llll}
\hline $\begin{array}{l}\text { SOURCE OF } \\
\text { VARIATION }\end{array}$ & $\begin{array}{l}\text { Genotypic } \\
\text { Variance }(\boldsymbol{\sigma 2 g})\end{array}$ & $\begin{array}{l}\text { Phenotypic } \\
\text { Variance }(\boldsymbol{\sigma} 2 \mathbf{p})\end{array}$ & Heritability (h2) \\
\hline Plant Height & 557.17 & 682.15 & 0.82 \\
Leaf Length & 706.82 & 848.4 & 0.83 \\
Leaf Width & 8.915 & 9.55 & 0.93 \\
Number of Leaves & 9.14 & 10.24 & 0.89 \\
Number Tassels & 9.85 & 10.87 & 0.91 \\
Length of Tassels & 56.5 & 62.77 & 0.90 \\
Dry Shoot Biomass & 1.13 & 1.49 & 0.76 \\
Dry Root Biomass & 0.0025 & 0.0025 & 1.00 \\
Dry Leaf Biomass & 0.22 & 0.28 & 0.79 \\
Disease Incident & 8.27 & 62.44 & 0.13 \\
Root Lodging & 0.04 & 0.20 & 0.20 \\
\hline
\end{tabular}


Table 8: Nano Drop and DNA concentration of Treated Maize Genotypes

\begin{tabular}{|c|c|c|c|c|c|c|c|c|c|c|}
\hline \multirow[b]{2}{*}{ Genotypes } & \multicolumn{2}{|c|}{ Treatment 1} & \multicolumn{2}{|c|}{ Treatment 2} & \multicolumn{2}{|c|}{ Treatment 3} & \multicolumn{2}{|c|}{ Treatment 4} & \multicolumn{2}{|c|}{ Treatment 5} \\
\hline & $\begin{array}{l}\text { DNA } \\
(\mathbf{u l})\end{array}$ & $\begin{array}{l}\text { Conc } \\
\text { (0KV/Mas) }\end{array}$ & $\begin{array}{l}\text { DNA } \\
(\text { ul) }\end{array}$ & $\begin{array}{l}\text { Conc } \\
(85 K V / M a s)\end{array}$ & $\begin{array}{l}\text { DNA } \\
(\text { ul })\end{array}$ & $\begin{array}{l}\text { Conc } \\
(90 K V / M a s)\end{array}$ & $\begin{array}{l}\text { DNA } \\
(\text { ul) }\end{array}$ & $\begin{array}{l}\text { Conc } \\
(95 K V / M a s)\end{array}$ & $\begin{array}{l}\text { DNA } \\
(\text { ul) }\end{array}$ & $\begin{array}{l}\text { Conc } \\
(100 K \text { K/Mas })\end{array}$ \\
\hline TZM 1551 & 2841.6 & 1.88 & 985 & 1.81 & 188.1 & 1.43 & 311.6 & 1.47 & 612.7 & 1.83 \\
\hline $\begin{array}{l}\text { TZL COMP1 } \\
\mathrm{C}_{2}\end{array}$ & 1477.8 & 1.89 & 1040.4 & 1.8 & 957.8 & 1.59 & 1059.8 & 1.79 & 564.9 & 1.73 \\
\hline TZM 1318 & 1193.1 & 1.82 & 813.7 & 1.8 & 719.6 & 1.65 & 782.6 & 1.67 & 1608.6 & 1.89 \\
\hline TZM 132 & 2062.3 & 1.87 & 1255.4 & 1.85 & 988.5 & 1.81 & 788.3 & 1.8 & 2086.3 & 1.91 \\
\hline $\begin{array}{l}\text { TZE- } \\
\text { WDTSR }\end{array}$ & 473.9 & 1.7 & 938.5 & 1.88 & 977.6 & 1.85 & 805.1 & 1.61 & 1144.7 & 1.67 \\
\hline $\begin{array}{l}\text { OBA } \\
\text { SUPPER F }_{2}\end{array}$ & 893.3 & 1.8 & 400.8 & 1.69 & 1476.3 & 1.86 & & & 756.6 & 1.75 \\
\hline TZM 217 & 1076.2 & 1.82 & 1068.1 & 1.83 & 1122.6 & 1.59 & 1573 & 1.61 & 995.5 & 1.82 \\
\hline TZM 1300 & 1038.5 & 1.8 & 1161.4 & 1.76 & 936.5 & 1.82 & 630 & 1.85 & 392.8 & 1.58 \\
\hline DTSR- WCo & 848.8 & 1.79 & & & 226.4 & 1.73 & 1151.8 & 1.76 & 969.8 & 1.76 \\
\hline TZM 140 & 698.4 & 1.7 & 1423.1 & 1.89 & 820.1 & 1.69 & 1029.2 & 1.83 & 418.3 & 1.57 \\
\hline
\end{tabular}

DNA $(\mathrm{ul})=$ Extracted genomic DNA $(\mathrm{ul})$, Conc $=$ Concentration of Genomic DNA, 
Table 9: Frequency, Diversity of Allele and Polymorphic Information Contents (PIC) of Treated Maize Genotypes

\begin{tabular}{|c|c|c|c|c|c|c|c|c|c|c|}
\hline Primers & $\begin{array}{l}\text { Major Allele } \\
\text { Frequency }\end{array}$ & $\begin{array}{l}\text { Genotype } \\
\text { No }\end{array}$ & $\begin{array}{l}\text { Sample } \\
\text { Size }\end{array}$ & $\begin{array}{l}\text { Number of } \\
\text { observations }\end{array}$ & $\begin{array}{l}\text { Allele } \\
\text { No }\end{array}$ & Availability & $\begin{array}{l}\text { Gene } \\
\text { Diversity }\end{array}$ & Heterozygosity & PIC & $\begin{array}{l}\text { PIC } \\
(\%)\end{array}$ \\
\hline UMC2151 & 0.47 & 3 & 48 & 32 & 3 & 0.67 & 0.64 & 0.00 & 0.56 & 56.15 \\
\hline BMC1755 & 0.39 & 3 & 48 & 23 & 3 & 0.48 & 0.66 & 0.00 & 0.59 & 58.77 \\
\hline ZCT197 & 0.53 & 3 & 48 & 30 & 3 & 0.63 & 0.55 & 0.00 & 0.46 & 45.61 \\
\hline ZMCP 7430 & 0.60 & 3 & 48 & 45 & 3 & 0.94 & 0.52 & 0.00 & 0.44 & 44.03 \\
\hline BMC 1520 & 0.80 & 3 & 48 & 46 & 3 & 0.96 & 0.33 & 0.00 & 0.30 & 29.55 \\
\hline UMC 1295 & 0.93 & 2 & 48 & 44 & 2 & 0.92 & 0.13 & 0.00 & 0.12 & 11.9 \\
\hline UMC 2281 & 0.50 & 4 & 48 & 48 & 3 & 1.00 & 0.54 & 0.08 & 0.43 & 43.16 \\
\hline UMC 1822 & 0.49 & 6 & 48 & 39 & 3 & 0.81 & 0.63 & 0.08 & 0.56 & 55.83 \\
\hline Mean & 0.59 & 3.375 & 48 & 38.375 & 2.875 & 0.78 & 0.50 & 0.02 & 0.43 & 43.12 \\
\hline
\end{tabular}


Odunayo J. Olawuyi, David F. Igata, 25

Volume 18, Number 2, October 2020, pp 1-25.

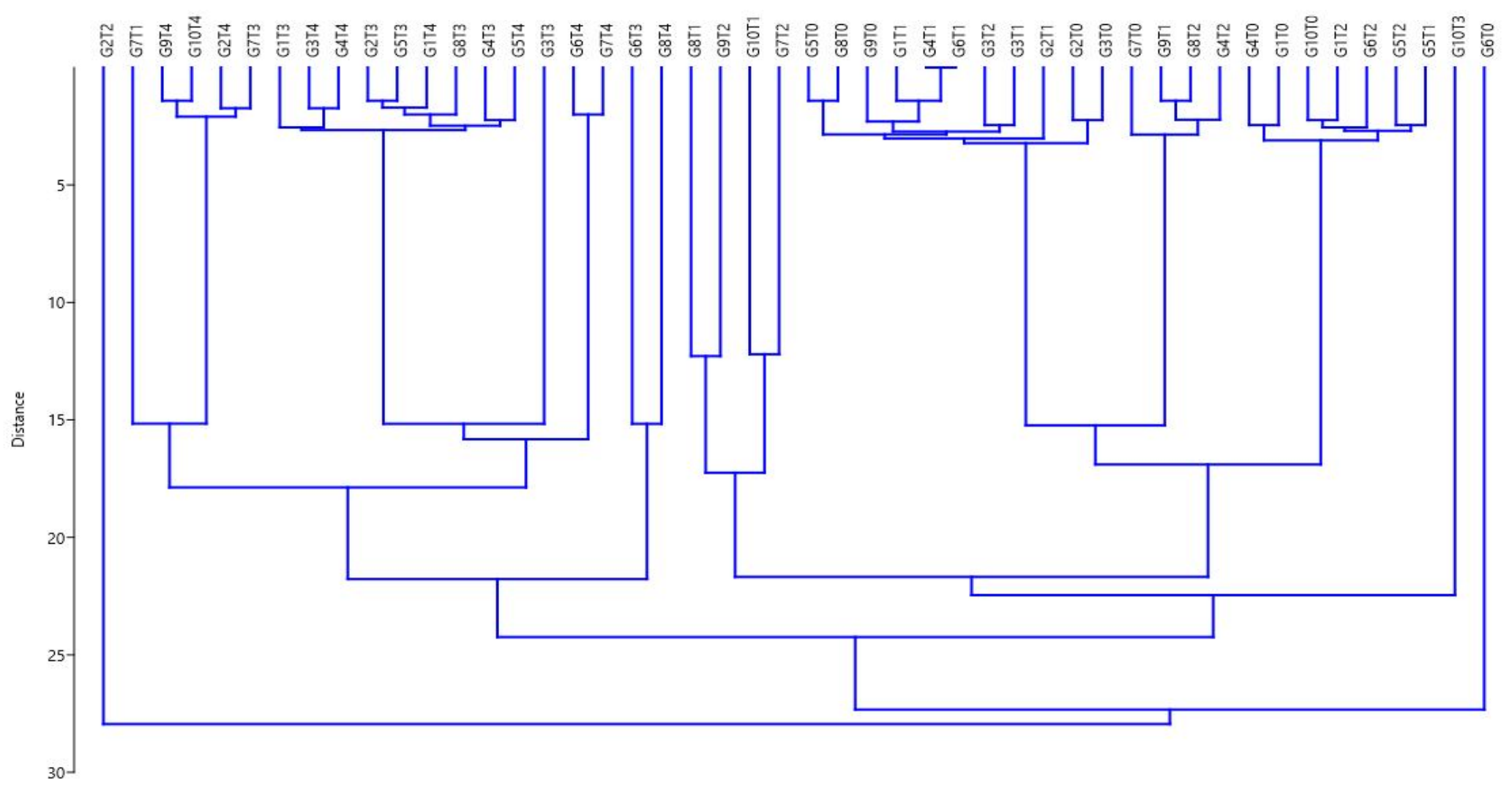

$\mathrm{G}_{1}=$ TZM 1551; $\mathrm{G}_{2}=$ TZM COMP1 $\mathrm{C}_{2} ; \mathrm{G}_{3}=$ TZM 1318; $\mathrm{G}_{4}=$ TZM 132; $\mathrm{G}_{5}=$ TZE-WDTSR $\mathrm{C}_{4} ; \mathrm{G}_{6}=$ OBA SUPPER FII G $=$ TZM $217 ;$ $\mathrm{G}_{8}=\mathrm{TZM} 1300 ; \mathrm{G}_{9}=\mathrm{DTSR}-\mathrm{WC}_{0} ; \mathrm{G} 10=\mathrm{TZM} 140 ; \mathrm{T}_{1}=85 \mathrm{KV} / \mathrm{MAS} ; \mathrm{T}_{2}=90 \mathrm{KV} / \mathrm{MAS} ; \mathrm{T}_{3}=95 \mathrm{KV} / \mathrm{MAS} ; \mathrm{T}_{4}=100 \mathrm{KV} / \mathrm{MAS} ;$ $\mathrm{T}_{0}=0 \mathrm{KV} / \mathrm{MAS}$.

Figure 1: Dendrogram showing genetic relationship among treated maize genotypes. 